\title{
タグチメソッドによるエ作機械設計のロバスト性評価法*
}

\author{
三 島 望 ${ }^{* *}$ 石井浩 介*** 森 和 男**
}

Robustness Estimation for Machine Tool Designs Using Taguchi Method

Nozomu MISHIMA, Kosuke ISHII and Kazuo MORI

\begin{abstract}
It is well known that the cutting motions of a machine tool can be expressed by a combination of homogeneous transformation matrices. One such combination, called the form-shaping function, relates both the machine tool structure and the product shape to the machining tolerance. This function allows the prediction of machining tolerances based upon knowledge of the machine and product geometry. This paper first describes a generalized procedure used to obtain the form-shaping function. Then, the Taguchi method is applied to the form-shaping function of a T-base lathe. The goal is to identify which physical dimension of the machine most strongly influences its tolerance-holding capability. The numerical results for the T-base lathe indicate that the distance between the spindle center and the base is the most critical parameter for improving machine robustness. The results also lead us to conclude that the Taguchi method is useful in determining an optimum design strategy for a machine tool.
\end{abstract}

Key words: homogeneous transformation matrix, robust design, form-shaping function, machining tolerance, Taguchi method, T-base lathe

$$
\text { 1.はじめに }
$$

工作機械には様々な形状の工作物を所望の加工精度内で安 定して加工を行うことが求められる。そのためには設計時に あらかじめ加工誤差の推定, 設計の評価が行えることが望ま しい. 加工誤差は工具と工作物との相対的位置関係で決定さ れる。そこで，その位置関係を解析的に記述し，設計しょう とする工作機械の構造に合わせて，その加工性能を評価する 研究が行わ机ている。この相対位置関係を記述する方法のう ち，良く知られたものに形状創成関数 12 がある。この形状 創成関数を加工誤差の予測，工作機械の設計評価に適用した 例 ${ }^{3 /}$ が報告されている。また，こ机とは独立に他の数学的表 現を用いて，工作機械の加工䛊差を解析・予測した研究 や, 誤差べクトルを用いて工作機械の幾何誤差を表現し, 数 値補正に応用した研究 ${ }^{(6)}$ 等も見られる.

これらの研究により工作機械における䛊差生成機構の解 明に関しては著しい進展をみた。しかし、こうした手法は機 械各部における誤差量が既知の場合に適用でき，新規に設計 する場合など，誤差量が未知の場合には加工誤差の予測が困 難である。つまり，任意の工作物形状や未知の組立誤差など の不確定な要因に対して安定して加工精度が発揮できるよう な工作機械構造のロバスト性を評価することはできない.

本研究では, 同次変換行列 ${ }^{1}(\mathrm{HTM})$ を用いた工作機械の形状 創成関数を導出し，これにタグチメソッドタ適用すること により，加工誤差やそのロバスト性に及ほす工作機械構造や 工作物形状の影響を同定する方法を提案する。解析対象とし ては, 工作機械の一般的な構造形式である Tベース旋盤を取 り上げ, 工作機械構造, 工作物の代表寸法と加工誤差との関

\footnotetext{
* 原稿受付 平成 10 年 4 月 22 日

** 正会員 機械技術研究所 (つくば市並木 1-2)

*** スタンフォード大学工学部（Stanford, CA 94305. USA）
}

係を明らかにする。この結果から, 本研究の方法により未知 の加工・組立誤差に対する工作機械設計を含む機械加工プロ セスのロバスト性を評価可能であることを示す．

\section{2. 形状創成動作の数学的表現}

\section{1 形状創成関数}

工作機械構造を図1に示すように工作物から工具へと連な る剛体要素の連鎖と考える。
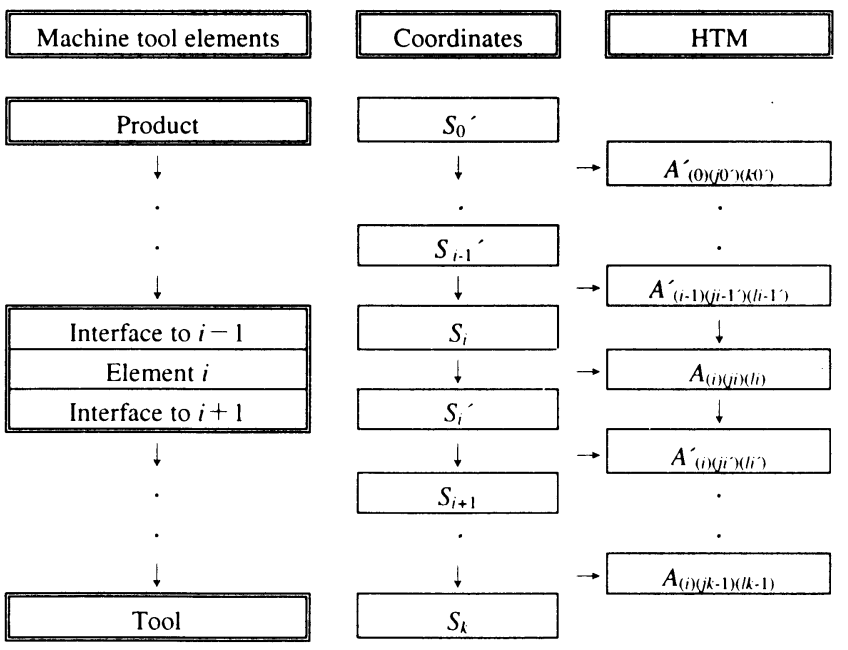

Fig.l Corresponding elements. coordinates and HTM

いま, 工作機械が要素 0 から要素 $k$ までの合計 $k+1$ 個の要 素が直列に連結された構造であるとし, 要素 $i(i=1-k-1)$ において, 要素 $i-1$ との界面に直交座標系 $S_{i}$, 要素 $i+1$ との界 面に $S_{i}$ を付与する。 ただし, 要素 $i=0$ は工作物, 要素 $i=k$ は工具とし， $S_{0}^{\prime} ， S_{k}$ だけを付与する。このようにすると， $S_{\mathrm{i}}$ $\rightarrow \mathrm{S}_{\mathrm{i}}{ }^{\circ}$ の変換は要素内部での座標変換, $S_{i} \rightarrow S_{i+1}$ の変換は要素 
間の座標変換を表すことになる。それぞれの座標変換を同次

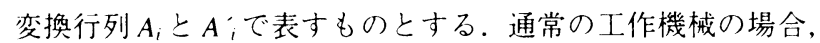
$A_{i}$ 拈よび $A$ iは $x, y, z$ 軸に沿った平行移動と $x, y, z$ 軸回り の回転移動のいずれか 1 種類で表される。これら 6 種類の座 標変換に対して， $x$ 軸に沿った平行移動を $1, y$ 軸に沿った平 行移動を 2 など 1 から 6 までの番号を与えて区別する．先に 定義した同次変換行列 $A_{i}, A^{\prime}$ ，がそれぞれ $j_{i}, j_{i}^{\prime}\left(j_{i}, j_{i}^{\prime}=1 \sim 6\right)$ 番目の変換で表され, 移動量（平行移動であれ就距離, 回転 移動であ机ば回転角) がく、に、で表される場合，これを $A_{(i)(j)(l i t}$

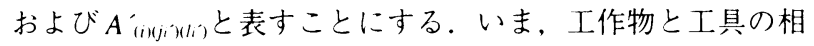
対変位をべクトル $\vec{r}_{0}$ で表し，工具に付与された座標系におい て，工具取付け点を原点としたときの工具先端位置べクトル を工具形状と定義し，これを $\vec{r}_{t}$ で表す． $\vec{r}_{0}$ と $\vec{r}_{t}$ の関係は式(1) により表され， $\vec{r}_{0}$ が工作機械の形状創成関数である。

$$
\vec{r}_{0}=A_{(0)\left(j_{0}\right)\left(l_{0}\right)}^{\prime} \cdot A_{(i)\left(j_{i}^{\prime}\right)\left(l_{i}^{\prime}\right)}^{\prime} A_{(i+1)\left(j_{i+1}\right)\left(l_{1+1}\right)}
$$

$$
\cdot A_{(k-1)\left(i_{k-1}^{\prime}\right)\left(l_{k-1}^{\prime}\right)}^{\prime} \vec{r}_{t}
$$

$\left(j_{11}, \cdots, j_{i}, j^{\prime} i^{\prime}, j^{\prime}{ }_{k-1}=1-6\right)$

( $l^{\prime}, \cdots, \cdots, l_{i}, l_{i}^{\prime} \cdots, l_{k-1}^{\prime}$ は任意の移動量)

\section{2 形状創成誤差関数}

実際の工作機械には組立誤差, 熱変形, 経年変化, 摩耗, 外力による変形など多くの誤差要因が存在する。こ机らの䛊 差は座標変換の際に, 平行移動誤差または回転誤差として現 れるので，実際の機械における形状創成動作を記述するため にはこ礼らの䛊差を考慮しなくてはならない。こうした䛊差 は, 要素内部の変換, 要素間の変換のどちらにも現札うる。 しかし，便宜上どちらかの変換に集䄪して取り扱うことがで きるので，本論文では，これらの誤差を要素間の変換に含め るものとする。そこでいま，要素間の変換 $S_{i}{ }^{\circ} \rightarrow S_{i+1}$ における $x$, $y, z$ 軸回りの回転誤差を $\alpha_{i}, \beta_{i}, \gamma_{i}$ とし, 平行移動誤差を $\delta_{x i}$, $\delta_{i}, \delta_{i i}$ と表すものとする。このとき, $S_{i}{ }^{\prime} \rightarrow S_{i+1}$ の変換における 誤差成分を含む同次变換行列 $A_{e^{i}}$ は次の式で表される.

$$
A_{\varepsilon_{i}}=\left[\begin{array}{cccc}
1 & -\gamma_{i} & \beta_{i} & \delta_{x i} \\
\gamma_{i} & 1 & -\alpha_{i} & \delta_{y i} \\
-\beta_{i} & \alpha_{i} & 1 & \delta_{z i} \\
0 & 0 & 0 & 1
\end{array}\right]
$$

式(1)における $A_{(i)(j)(l)}^{\prime}$ と $A_{(i+1)\left(j_{i+1}\right) K_{i+1}}$ との間の要素間変換に式 (2)を挿入することにより, 誤差を含む形状創成関数 $\vec{r}_{\varepsilon 0}$ が次 式のように表される。

$$
\begin{aligned}
\vec{r}_{\varepsilon 0}= & A_{(0)\left(j_{0}\right)\left(l_{0}\right)}^{\prime} A_{\varepsilon 0} \cdot A_{(i)\left(j_{i}^{\prime}\right)\left(l_{i}^{\prime}\right)}^{\prime} A_{\varepsilon i} A_{(i+1)\left(j_{i+1}\right)\left(l_{i+1}\right)} \\
& \cdot A_{(k-1)\left(j_{k-1}^{\prime}\right)\left(l_{k-1}^{\prime}\right)}^{\prime} \vec{r}_{t}
\end{aligned}
$$

また，形状創成誤差関数 $\Delta \vec{r}_{0}$ は, 䛊差を含まない形状創成 関数と誤差を含んだ形状創成関数との差として定義され, 次 式で表すことができる。

$$
\Delta \vec{r}_{0}=\vec{r}_{\varepsilon 0}-\vec{r}_{0}
$$

\section{3. 丁ベース旋盤における形状創成動作のロバスト性評価法}

次に工作機械の基本的な形式の一種である Tベース型の旋 盤を取り上げ，その形状創成関数から加工誤差やそのロバス 卜性に与える工作機械形状の影響を同定する方法を検討する.

\section{1 形状創成関数の導出}

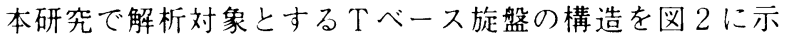

す、隣接する座標系間の変換が 1 種類の平行または回転移動 によって表現できるよう，この旋盤の要素を工作物, 主軸, 主軸頭, ベース, 工具台, 工具に分けている。

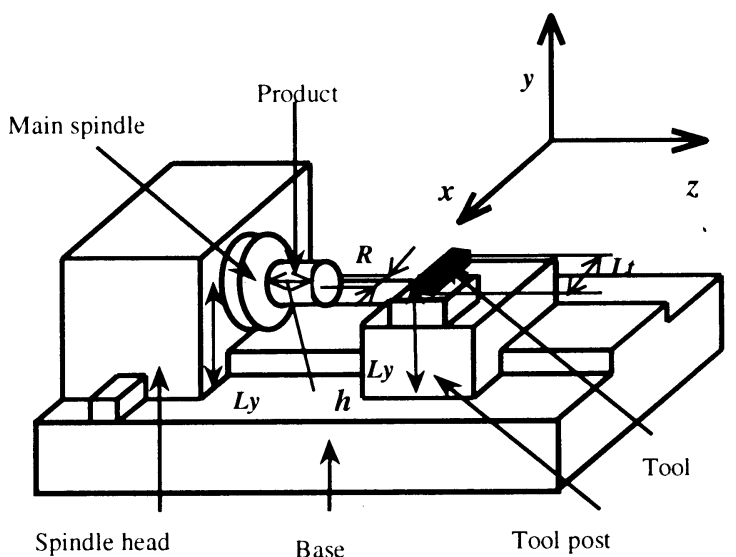

Fig.2 Schematic view of the T-base lathe

図に示すように工作物の高さを $h$, 半径を $R$, 主軸中心の ベース面からの距離を $L y$, 工具長さを $L t$, 工具と $x$ 軸のなす 角を $\theta$ とする。このとき工具先端のベース面からの距離も $L y$ となる。こ机ら要素の結合順と, 対応する座標系, 同次変換 行列を図 3 に示す。

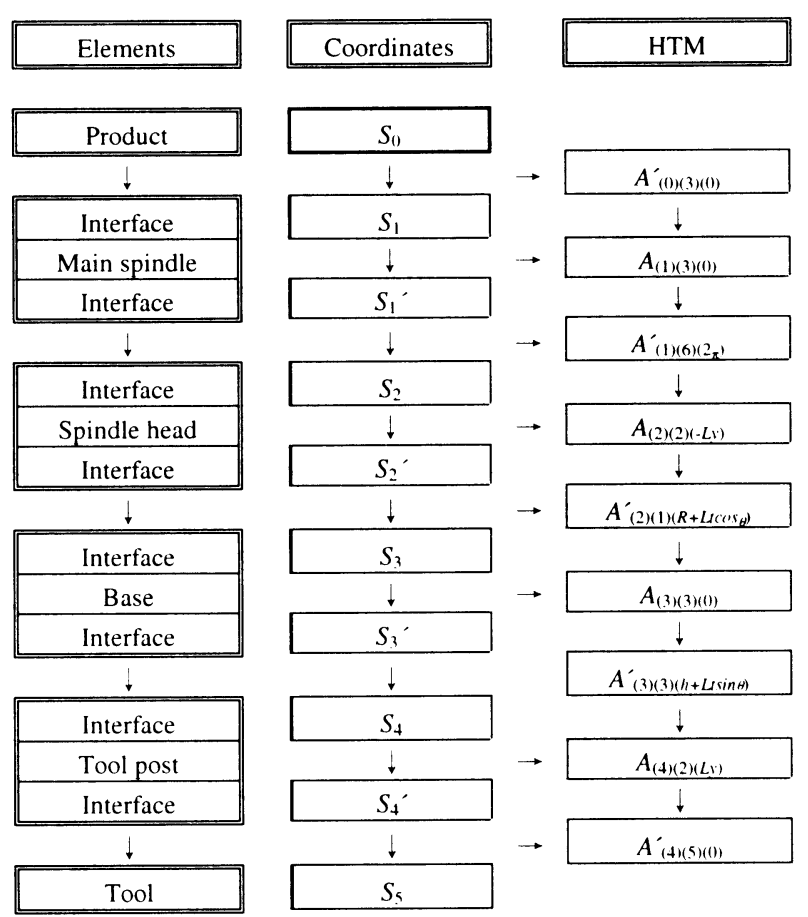

Fig.3 Corresponding elements, coordinates and HTM for the T-base lathe

図中の同次変換行列において, $A^{\prime}(())(3)(1)$ のように移動量が 0 である変換は, 䛊差を考慮しない場合無視できるので, 図 2

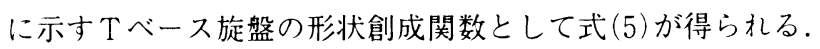

$$
\vec{r}_{0}=A_{(1)(6)(2 \pi)}^{\prime} A_{(2)(2)(L y)} A_{(2)(1)(R+L t \cos \theta)}^{\prime}
$$

$$
A_{(3)(3)(h+L t \sin \theta)}^{\prime} A_{(4)(2)(L y)} \cdot \vec{r}_{t}
$$


また, 工具形状べクトル $\vec{r}_{t}$ は定義より次の式 (6)で表される

$$
\vec{r}_{t}=\left\{\begin{array}{llll}
-L t \cos \theta & 0 & -L t \sin \theta & 1
\end{array}\right\}^{T}
$$

\section{2 形状創成誤差関数の導出}

工作機械の局所的誤差は式 (2) で定義した 6 種類の誤差パ ラメー夕， $\alpha_{i} ， \beta_{i} ， \gamma_{i} ＼delta_{x i} ， \delta_{i i} ， \delta_{i i}$ を用いて表すことができる. こ机らの誤差は要素間の変換に際してのみ考慮す机ばよいか ら, 図 3 のうちの要素間变換 $S_{i}^{\prime} \rightarrow S_{i+1}$ に式(2)に定めた $A_{a^{\prime}}$ を 挿入し, 誤差を含む形状創成関数が次式により求めら机る.

$\vec{r}_{\varepsilon 0}=A_{\varepsilon 0} A_{(1)(6)(2 \pi)}^{\prime} A_{\varepsilon 1} A_{(2)(2)(-L y)} A_{(2)(1)(R+L t \cos \theta)}^{\prime}$

$$
A_{\mathcal{E} 2} A_{(3)(3)(L t \sin \theta)}^{\prime} A_{\mathcal{E} 3} A_{(4)(2)(L y)} A_{\mathcal{E} 4} \cdot \vec{r}_{t}
$$

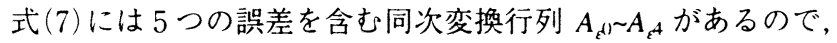
各変換における誤差パラメー夕をそ机ぞれ定義し, 表 1 のよ うに表すことにする。

\begin{tabular}{|c|c|c|}
\hline \multirow[t]{2}{*}{ HTM } & \multicolumn{2}{|c|}{ Error parameters } \\
\hline & Rotational error & Transitional error \\
\hline$A_{d}$ & $\alpha_{1}, \beta_{i}, \gamma_{i}$ & $\delta_{x(1)}, \quad \delta_{10}, \quad \delta_{01}$ \\
\hline$A_{s 1}$ & $\alpha_{1}, \beta_{1}, \gamma_{1}$ & $\delta_{11}, \delta_{11}, \delta_{-1}$ \\
\hline$A_{s^{2}}$ & $\alpha_{2}, \beta_{2}, \gamma_{2}$ & $\delta_{x 2}, \quad \delta_{2}, \quad \delta_{2}$ \\
\hline$A_{i 3}$ & $\alpha_{3}, \beta_{3}, \gamma_{3}$ & $\delta_{23}, \quad \delta_{13}, \quad \delta_{3}$ \\
\hline$A_{s}$ & $\alpha_{4}, \beta_{4}, \gamma_{4}$ & $\delta_{14}, \quad \delta_{4}, \delta_{4}$ \\
\hline
\end{tabular}

Table 1 Error parameters

ここで, 実際のTベース旋盤の構造を考慮すると, 表 1 の 誤差パラメータについて以下の仮定が成り立つと考えら礼る.

A） $A_{\mathrm{k}^{0}}$ において工作物の主軸への取付誤差は無視できる.

B） $A_{\varepsilon 1}$ において, $\gamma_{1}$ は $z$ 軸回りの回転誤差であり, 同方向で ある主軸自体の回転に比べて微小なので無視できる。

C) $\beta_{4}$ は工具台の $z$ 方向案内面に対寸る回転誤差である, 同 方向の工具取り付け角に比べ，微小なので無視できる。

D) 工具は工具台に対して平行移動は行わないので, 平行移 動誤差 $\delta_{x 4}, \delta_{14}, \delta_{i 4}$ は考慮する必要が無い.

E） $\delta_{x 1}$ と $\delta_{11}$ は主軸の中心軸の偏心量に相当するので $x, y$ 方 向を区別せず $\delta_{x 1}=\delta_{i 1}$ とする.

F） $\delta_{i 2}$ は発熱に起因する主軸の伸びであるので，その大き さは主軸頭のべースからの距離に比例するものと考え， 次のように式(8)で表す.

$\delta_{z 1}=c_{1} \times L y$

ここで $c_{1}$ は比例係数で, その值については後述する.

G） $\delta_{x 2}$ と $\delta_{x 3}$ はそれぞれ $x, z$ 軸のスケール誤差として定義さ 机るもので, 工作機械全体の均一な温度上昇に起因する と考えられる。そこで，次式が成り立つものとする。 $\delta_{\times 2}=c_{2} \times R$

$\delta_{z_{3}}=c_{2} \times h$

ここで， $c_{2}$ は比例係数である

H） $\delta_{22} ， \delta_{12}$ および $\delta_{x 3} ， \delta_{13}$ はそ机ぞれ，案内面の粗さ，駆動 用のボールねじの回転むらなど同一の原因に起因する ものと仮定し， $\delta_{22}=\delta_{12}, \delta_{x 3}=\delta_{13}$ とする.

I）主軸頭の傾き $\alpha_{1}, \beta_{1}$, ベースの傾き $\alpha_{2}, \beta_{2}, \gamma_{2}$, 工具台の 傾き $\alpha_{3}, \beta_{3}, \gamma_{3}$, 工具の傾き $\alpha_{1}, \gamma_{1}$ はすべて独立である. こ机らの仮定により独立な誤差パラメー夕は表 2 に示す ように 15 個となる。
Table 2 Considered error parameters

\begin{tabular}{c|c}
\hline Parameters & Error description \\
\hline$\alpha_{1}, \beta_{1}$ & Spindle head inclination \\
\hline$\delta_{11}$ & Spindle eccentricity \\
\hline$\delta_{1}$ & Spindle expansion to $z$ direction \\
\hline$\alpha_{-}, \beta_{2}, \gamma_{2}$ & Base inclination \\
\hline$\delta_{12} \delta_{3}$ & Scale error \\
\hline$\delta_{12}$ & Straightness error of $x$ slider \\
\hline$\alpha_{3}, \beta_{3}, \gamma_{3}$ & Tool post inclination \\
\hline$\delta_{13}$ & Straightness error of $z$ slider \\
\hline$\alpha_{1}, \gamma_{1}$ & Tool inclination \\
\hline
\end{tabular}

式(4)一 (9)より, 対象とする Tベース旋盤の形状創成誤差 関数は式(10)のように求められる.

$$
\Delta \vec{r}_{0}=\left[\begin{array}{c}
\delta_{x 1}+c_{2} \cdot R+\delta_{y 3}+\left(\beta_{1}+\beta_{2}\right) \cdot h \\
-\left(\gamma_{2}+\gamma_{3}\right) \cdot L y-\left(\beta_{2}+\beta_{3}\right) \cdot L t \sin \theta \\
\delta_{x 1}+\delta_{y 2}+\delta_{y 3}-\left(\alpha_{1}+\alpha_{2}\right) \cdot h \\
+\left(\gamma_{2}+\gamma_{3}+\gamma_{4}\right) L t \cos \theta+\left(\alpha_{3}+\alpha_{4}\right) \cdot L t \sin \theta \\
c_{1} \cdot l y+\delta_{y 2}+c_{2} \cdot h-\alpha_{1} \cdot R \\
+\left(\alpha_{1}+\alpha_{2}+\alpha_{3}\right) \cdot L y+\left(\beta_{2}+\beta_{3}\right) \cdot L t \sin \theta \\
0
\end{array}\right]
$$

\section{3 タグチメソッドの適用}

式（10）において，すべての誤差パラメータが既知の場合 は形状創成誤差関数 $\Delta \vec{r}_{0}$ は単純な演算で求めることができる. ところが, 工作機械の設計時には, あらかじめ構成要素の加 工誤差や組立誤差を見積もることは困難であるため, 式 (10) を直接解くことはできない.しかし様々な加工条件下で安定 した加工精度が得ら札る設計を行うためには, 未知の誤差バ ラメータに対してロバストな設計を実現することが必要であ る。つまり，未知の誤差パラメータを含んだままで形状創成 誤差関数, 式（10）を評価できる方法が必要である。 その一 つとしてタグチメソッドがあげられる，タグチメソッドは実 験計画法や品質工学の分野で広く普及している方法であり, プロセスなどのロバスト性を評価できる。ここでは, 誤差バ ラメータが未知である設計の初期段階において，工作機械の 構造が加工誤差に及ぼす影響をタグチメソッドによって評価 できるものと考え, 解析式である形状創成誤差関数に適用寸 る.

\section{4 評価関数の設定}

タグチメソッドでは，ある範囲内で変動するノイズファク 夕の下で評価関数を最適化するコントロールファクタの值の 組み合わせを求める。そこでまず本問題における評価関数の 設定が必要である。評価関数の取り方については様々に考え ら札るが, 本例では, 半径 $R$, 高さhの円筒状の工作物を考 え, 点 $(R, 0, h) に$ に扔ける誤差量に注目する。この点を目標と して工具上工作物を相対変位させたときの各軸方向の誤差量 を $\Delta x, \Delta y, \Delta z$ で定義し,$\left(\Delta x^{2}+\Delta y^{2}\right)^{12 を}$ を半径䛊差， $\Delta z$ を高 さ䛊差と呼ぶ。また， $\left(\Delta x^{2}+\Delta y^{2}+\Delta z^{2}\right)^{12}$ を棇合誤差と定義する。 本研究では, 評価関数を総合誤差とした場合, 半径誤差とし た場合, 高さ誤差とした場合の 3 通りについて評価を行う。 


\section{5 ノイズ、コントロールファクタの変動範囲の設定}

評価関数の計算を行う際には，適切なコントロールファク 夕, ノイズファク夕を選定し, その変動範囲を設定しなくて はならない, 本研究の例では, 工作物の半径 $R$, 高さ $h$, 工具 取付角 $\theta$, 主軸中心のベッド面からの高さ $L y$ をコントロール ファクタとし, 表 2 の誤差パラメータをノイズファクタとす ることができる.コントロールファクタについてはその加工 誤差への寄与の様子が明らかでないので，それぞれについて 3 種類の值を用いる。 そこでコントロールファクタには L9." の直交配列を適用し，その值の組み合わせをLow, Mid, High という表現を使って表3のように表す.

Table 3 L9 Orthogonal array

\begin{tabular}{c|c|c|c|c}
\hline Number of run & $R$ & $h$ & $\theta$ & $L y$ \\
\hline 1 & Low & Low & Low & Low \\
\hline 2 & Low & Mid & Mid & Mid \\
\hline 3 & Low & High & High & High \\
\hline 4 & Mid & Low & Mid & High \\
\hline 5 & Mid & Mid & High & Low \\
\hline 6 & Mid & High & Low & Mid \\
\hline 7 & High & Low & High & Mid \\
\hline 8 & High & Mid & Low & High \\
\hline 9 & High & High & Mid & Low \\
\hline
\end{tabular}

コントロールファクタの変動範囲は, Tベース旋盤におけ る一般的な值を考慮し，表 4 に示すようにとる。

Table 4 Range of the control factors

\begin{tabular}{|c|c|c|c|}
\hline \multicolumn{2}{|c|}{ Name of the factor } & Parameters & Range \\
\hline \multicolumn{2}{|c|}{ Product diameter } & $R$ & $0.1,0.2,0.3 \mathrm{~m}$ \\
\hline \multicolumn{2}{|c|}{ Product height } & $h$ & $0.1 .0 .2 .0 .3 \mathrm{~m}$ \\
\hline \multirow{3}{*}{ Tool angle } & Overall & \multirow{3}{*}{$\theta$} & $30,45,60^{\circ}$ \\
\hline & Radial & & $-45,0,45^{\circ}$ \\
\hline & Axial & & $30.60 .90^{\circ}$ \\
\hline \multicolumn{2}{|c|}{ Main spindle - base distance } & $L y$ & $0.3,0.4,0.5 \mathrm{~m}$ \\
\hline
\end{tabular}

一方, ノイズファクタに関しては, 表 2 の誤差パラメータ をノイズファク夕としたので, 誤差パラメータの変動範囲を 設定しなけ机ばならない。タグチメソッドではノイズファク 夕の厳密な值を設定する必要はなく, ある幅を持った変動範 囲を定め札ばよい。そこで, 表 2 の䛊差パラメータについて, 常識的に考えられる表 5 に示すような值を設定する.ただし， 主軸の伸び $\delta_{21}$, スケール䛊差 $\delta_{x 2}, \delta_{13}$ については值そのもので はなく，その比例係数 $c_{1} ， c_{2}$ を定める.

工作機械の特性を考えれば，ノイズファク夕，この場合誤 差パラメータは出力である加工誤差に対して単調に作用する と考えら札るので直交配列における变数のレベルは2つで充

Table 5 Range of the noise factors

\begin{tabular}{c|c|c}
\hline Error description & Prameters & Range \\
\hline Spindle expansion & $c_{1}$ & $0 \sim 2 \times 10^{-5}$ \\
\hline Scale error & $c_{2}$ & $0 \sim 5 \times 10^{-5}$ \\
\hline Spindle eccentricity & $\delta_{11}$ & $\pm 10 \mu \mathrm{m}$ \\
\hline Straightness error & $\delta_{12}=\delta_{2}$ & $\pm 10 \mu \mathrm{m}$ \\
& $\delta_{13}=\delta_{3}$ & \\
\hline Spindle inclination & $\alpha_{1} \alpha_{2}$ & $\pm 0.003^{\circ}$ \\
\hline Angular error & $\alpha_{2} \gamma_{2} \alpha_{3} \beta_{3}$ & $\pm 0.003^{\circ}$ \\
& $\alpha_{1} \gamma_{1}$ & \\
\hline
\end{tabular}

分だと考えら机る。そこで，ノイズファクターにはL16"の直 交配列を用いる。 また, 式（10）の変数のうち, 工具長さに ついては， $L t=0.1 \mathrm{~m}$ の一定值とする。

\section{6 計算結果について}

タグチメソッドによって規定された直交配列に基づき， 表 4，5の值を式（10）に代入し, 計算を行う．1セットの 計算は, 4 種類のコントロールファクタからなる 9 通りの組 み合わせのぞれぞ机に対して, 独立な 15 種のノイズファクタ からなる 16 通りの組み合わせについて計算することから構 成さ机る。計算結果は表 5 に示した範囲内でノイズファタタ が変動する場合に，各コントロールファクタが式(11)，(12) に示寸評価関数の平均值 $f_{e n}$ および, $\mathrm{S} / \mathrm{N}$ 比 $S n$ に及ほす影響 を示す。

$$
\begin{aligned}
& f_{e_{m}}=\sum_{i=1}^{n} f_{e_{i}} / n \\
& S n=-10 \log \left(V+f_{e m}\right)
\end{aligned}
$$

ここに, $n$ はシミュレーションの試行回数（ここでは $n=16 ）$, $f_{e i}$ は $i$ 番目の試行における評価関数の值，Vは分散である. この S/N 比がロバスト性の指標として広く用いられている。 この例では，まず評価関数を総合誤差とした場合について， 評価関数の平均值 $f_{e m}, \mathrm{~S} / \mathrm{N}$ 比 $S n$ とコントロールファクタの関 係について解析を行った。こ机らの結果を図 $4(\mathrm{a}),(\mathrm{b})$ に示 す. 同様の計算を半径䛊差, 高さ䛊差についても行い, 評価 関数の平均値に関する結果を図 $4(\mathrm{c}), 4(\mathrm{~d})$ に示す.

図において各コントロールファクタに対応する線分の傾き が急である時，そのファクタが加工誤差ないし S/N 比に与え る影響が大きいことを意味する．図 4(a)ではすべての線分が 右肩上がりになっており，コントロールファクタの值が小さ いほど加工誤差も小さいことを示す. 図 4(b)はコントロール ファクタの值が小さいほど $\mathrm{S} / \mathrm{N}$ 比が高い, つまり組立誤差な どの外乱に対してロバストであることを示す.計算結果から， 対象としたTベース旋盤について以下が言える。

A）加工䛊差に与える影響が最も大きいのは主軸のベース上 面からの高さ Lyである.

B）ついで影響が大きいのは工作物高さhであり，工作物半 径 $R$ の影響より大きい.

C) 工具取付角 $\theta$ が加工䛊差に与える影響は大きくないが, 角度が小さい場合の方がわずかに誤差が小さい。

D） S/N 比に関しても傾向は同じであり, 加工のロバスト性 を高めるには $L y$ を小さくすることが有効である.

\section{4. 考察}

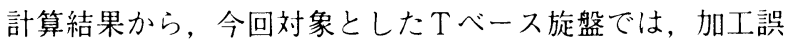
差に対して最も影響するのは主軸中心のベースからの高さで あることが明らかになった。そこで，このような情報を用い て, 工作機械設計において, 主軸回転中心と $z$ 方向案内面の オフセットが少ない工具台形状とするとロバスト性に優れた 設計になる，というような具体的設計指針を得ることができ る.

このように，形状創成関数にタグチメソッドを適用して工 作機械による加工のロバスト性を評価することを行ってみた 結果, 本手法は, 未知のノイズファク夕に対してのおおまか な情報だけで, 加工や工作機械の設計のロバスト性を評価で 


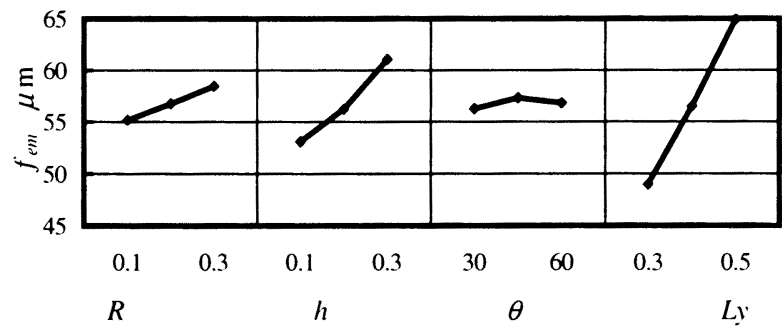

(a) Relation between overall error and control factors

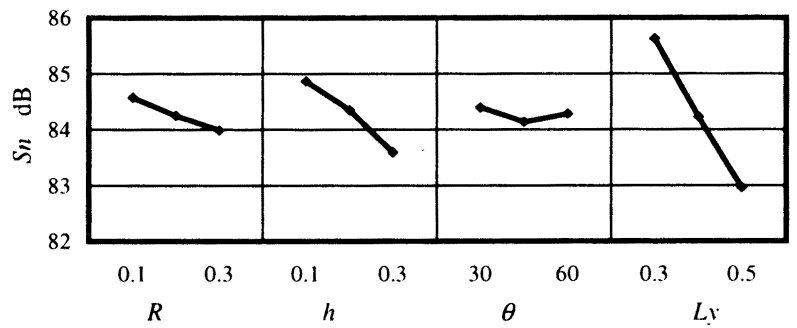

(b) Relation between $\mathrm{S} / \mathrm{N}$ ratio and control factors

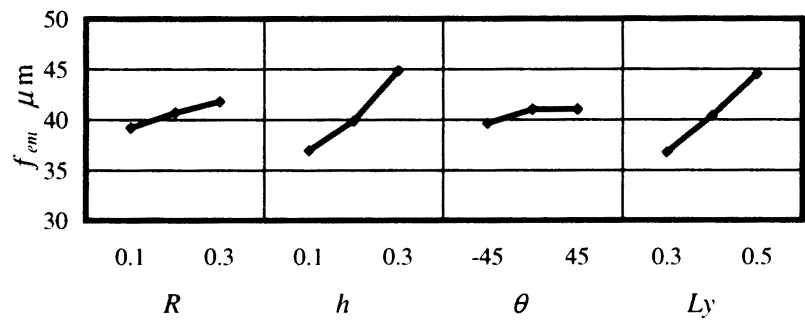

(c) Relation between radial error and control factors

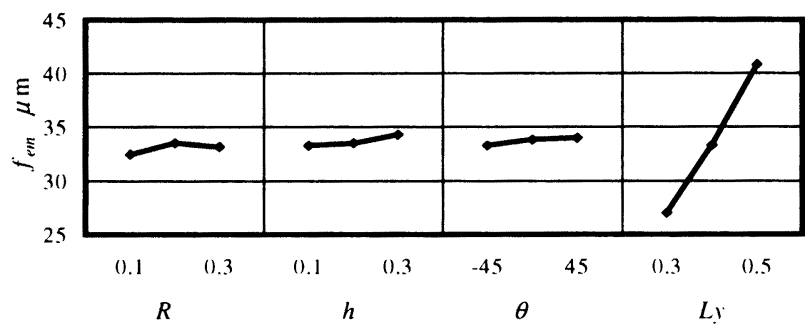

(d) Relation between axial error and control factors

Fig.4 Results of the calculation

きることが明らかになった。したがって，形状創成関数と夕 グチメソッドを組み合わせたロバスト設計手法は，機械設計 ないし工程設計の初期段階においてその最適構造の検討を行 うために有用なツールになりうると考えられる。形状創成関 数そのものはそれぞれの工作機械構造に固有であるものの， 本方法は様々な構造形式の工作機械の評価に適用できる。
たすべて解析的に行える方法なので,コントロールファク夕， ノイズファク夕にどのような変数を選ぶかには自由度が高く， 例えば，工作物寸法をノイズファクタとし，誤差パラメータ をコントロールファクタとすることも可能である。それによ り, 工作機械の各種䛊差パラメータのうち, ど狄が加工精度 に対して最も支配的かを明らかにすることもできる。これら の誤差パラメータは工作機械の部品の加工誤差, 仕上げ䛊差, 組立の際のアライメント誤差などに起因するので, 工作機械 の製作時にどの部分の誤差に最も着目し，公差を厳しくすべ きかを示唆できよう。このように決定したコントロールファ ク夕に対して，具体的な示唆が得られる一方，コントロール ファク夕を変更することにより, 他の場合にも適用できる柔 軟性も備えている点が本方法の特徵である。

$$
\text { 5. ま め }
$$

以上により得られた結果は以下のようにまとめられる。

（1）形状創成関数にタグチメソッドを適用した工作機械設 計のロバスト性評価手法を具体例により示した。

（2）本方法により工作機械構造や工作物の寸法などが加工 のロバスト性に与える影搖を評価できることを示した。

本方法の利点である, 設計の初期段階において設計の評価 ができる点をより有効に活用するために，工作機械の概念設 計段階に本方法を適用し，概念設計段階における設計におけ るロバスト性比較の考え方 ${ }^{10}$ 'を導入することが今後の研究課 題としてあげられる。これにより，異なる設計コンセプト間 での加工性能比較も含めた, トータルな工作機械の設計プロ セスにおいて強力な評価ツールを提供できよう.

\section{参 考 文 献}

1) D. N. Reshtov and V. T. Portman: Accuracy of Machine Tools, ASME Press, New York (1988).

2) 稲崎一郎, 岸浪建史, 竹内芳美, 杉村延広: 工作機械の形状創 成理論，羡賢堂，東京（1997）

3) A. H. Slocum: Precision Machine Design, Prentice Hall, Englewood Cliffs (1992).

4) 杉村延広ほか：工作機械の設計に対する解析的アプローチ(形 状創成過程のモデル化とその分析), 日本機械学会論文集 (C 編)，47, 418，(1981）793.

5) 坂本重彦, 稲崎一郎：5 軸マシンニングセンタの創成運動解析, 日本機械学会論文集 (C 編)，59，561，(1993），1553.

6）竹内芳美ほか：計算機補正による数値制御工作機械の加工精度 向上（第 2 報），精密機械，46，12（1980）79.

7) R. P. Paul: Robot Manipulators -Mathematics, Programming and Control-, The MIT Press, Cambridge (1981).

8) G. Taguchi and S. Konishi : Quality Engineering Series, Vol.1-4, ASI Press, New York (1991-1994).

9) W. Y. Folkes and C. M. Creveling: Engineering Methods for Robust Product Design, Addison Wesley, Menlo Park (1995).

10) R. B. Ford and P. Barkan: Beyond Parameter Design -A Methodology Addressing Product Robustness at the Concept Formation Stage, Proc. of ASME National Design Engineering Conf., (1995). 